\title{
ECPAS wt Allele
}

National Cancer Institute

\section{Source}

National Cancer Institute. ECPAS wt Allele. NCI Thesaurus. Code C158579.

Human ECPAS wild-type allele is located in the vicinity of 9q31.3 and is approximately 124 $\mathrm{kb}$ in length. This allele, which encodes proteasome adapter and scaffold protein ECM29, is involved in the assembly and cellular localization of the proteasome. 